\title{
Resource Nationalism in Indonesia-Effects of the 2014 Mineral Export Ban
}

\section{Introduction}

Resource nationalism encompasses a broad range of political and economic actions taken by Governments to regulate the extraction of natural resources within their borders. Policies such as increased tariffs or export restrictions can have far-reaching economic effects on international trade. As the Governments of several developing countries consider enacting nationalistic policies, an examination of the 2014 mineral export ban in Indonesia provides an instructive example of the possible impacts of resource nationalism. Significant changes in the production and trade of unprocessed (that is, ores and concentrates) and processed (that is, refined metal) aluminum, copper, and nickel before and after the export ban form the basis of this study.

The U.S. Geological Survey (USGS) National Minerals Information Center (NMIC) tracks production and trade of mineral commodities between producer and consumer countries. Materials flow studies clarify the effects of an export ban on different mineral commodities by assessing changes in production, processing capacity, and trade. Using extensive data collection and monitoring procedures, the USGS NMIC investigated the effects of resource nationalism on the flow of mineral commodities from Indonesia to the global economy.

\section{Legislation}

In 2009, the Indonesian Parliament passed a new Mining Law (Law No. 4) on Mineral and Coal Mining, to come into full effect in 2014. Among the requirements of Law No. 4 was the prohibition of exporting unprocessed ores, the obligation to process and refine the ores in Indonesia, and the requirement to pay higher export tariffs for specified mineral commodities. Also, foreign shareholders in companies were required to divest up to 51 percent of shares to Indonesian entities within 10 years from the commencement of commercial operation. The intent was to increase the production of higher value products in order to boost Government revenue derived from the mineral sector.

In 2014, the Government amended the principal regulations of the mining law and issued temporary permits for exports of partially processed minerals. The processing requirements for many minerals were decreased for a 3-year period and export duties were imposed at a progressive rate commencing at 20 percent in 2014 and increasing to 60 percent by 2017 . For example, purity requirements for copper were reduced to 15 percent from 99 percent and copper concentrates were subject to an export duty of 25 percent. Processing requirements, expected to increase in 2017, are currently being reviewed by the Government (Asmarini, 2016).

\section{Mine Production, Processing, and Trade}

In recent decades, Indonesia has been a major producer and exporter of several mineral commodities, including bauxite, copper concentrate, and nickel ore (fig. 1; all values for copper concentrate and nickel ore are reported as contained metal). Relative to total world mine production in 2013 , Indonesia accounted for 20 percent of bauxite production, 3 percent of copper in concentrate production, and 31 percent of nickel in ore production (Bray, 2016b; Brininstool, 2016; Kuck, 2016b). Following the ban on unprocessed mineral exports in January 2014, production of bauxite and nickel ore decreased dramatically, whereas copper concentrate output decreased only moderately. Relative to total world mine production in 2014, Indonesia accounted for 1 percent of bauxite production, 2 percent of copper in concentrate production, and 7 percent of nickel in ore production (Bray, 2016b; Brininstool, 2016; Kuck, 2016a). Although Indonesia was a major producer and the world's leading exporter of refined tin metal in 2013, exports of unprocessed tin ore had been prohibited since 2002 and were not directly affected by the 2014 ban (Tse, 2006; Anderson, 2015). Refined tin production in Indonesia has declined in recent years owing to low prices (Anderson, 2016).
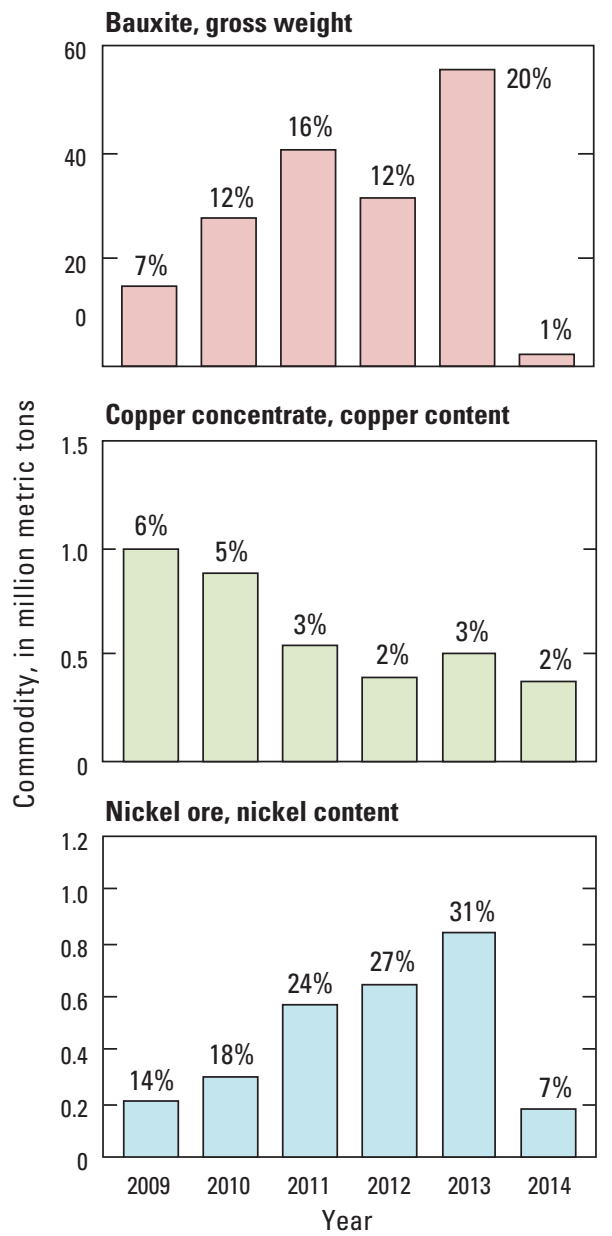

Figure 1. Indonesia's annual mine production of bauxite, copper concentrate, and nickel ore from 2009 through 2014 labeled with Indonesia's percentage of annual world production (Bray, 2015b, 2016b; Brininstool, 2015, 2016; Kuck, 2016a, b). 


\section{Bauxite, Alumina, and Aluminum}

Bauxite, an aluminum ore, occurs as intensely weathered deposits in tropical regions. In 2013, Indonesia produced a record output of 55.7 million metric tons (Mt) of bauxite, surpassing China to become the world's secondleading producer after Australia (fig. 1; Bray, 2016b). As a result of the mineral export ban, bauxite production fell by more than 95 percent to $2.6 \mathrm{Mt}$ in 2014 and an estimated $1 \mathrm{Mt}$ in 2015 (Bray, 2016a). Aluminum smelter output remained unchanged at 250,000 metric tons (t) in 2013 and 2014 (fig. 2;

Bray, 2015a).

Bauxite export revenue declined from $\$ 1.3$ billion in 2013 to $\$ 46$ million in 2014 (fig. 3; United Nations Statistics Division, 2016). Relative to the total value of exports of mineral commodities containing aluminum, copper, and nickel, in processed and unprocessed forms, bauxite and aluminum exports decreased from 20 percent of Indonesia's exports in 2013 to only 6 percent in 2014. China's aluminum industry consumed 97 percent of the bauxite exported by Indonesia between 2005 and 2014. Indonesia's record bauxite production in 2013 was attributed to stockpiling by Chinese alumina refineries in anticipation of the export ban (Bray, 2015b). Following implementation of the ban, bauxite production in China increased, bauxite stocks were drawn down, and production in Australia and Malaysia increased to meet demand from China (Rusmana, 2015; Bray, 2016a).

The dramatic decrease in bauxite production after the export ban reflected the lack of downstream processing capacity and poor integration between bauxite mines, alumina refineries, and aluminum smelters in Indonesia. Indonesia's bauxite producers include state-owned enterprise PT Aneka
Tambang Tbk (PT Antam), as well as foreign-owned companies and numerous small mining operations. Prior to the ban, all bauxite produced in Indonesia was exported for processing, as no alumina refineries and only one aluminum smelter operated within the country. Stateowned enterprise PT Indonesia Asahan Aluminium (PT Inalum) imported alumina to produce aluminum metal at its Kuala Tanjung smelter in North Sumatra.

In anticipation of the export ban, construction of several new facilities for domestic bauxite or alumina processing was proposed; among these were four alumina refineries and two aluminum smelters with reported design capacities (table 1). In 2014, PT Antam produced bauxite for a chemical-grade alumina refinery in Tayan, West Kalimantan, to be operated by PT Indonesia Chemical Alumina, a jointly controlled entity owned by PT Antam (80 percent) and Japan-based Showa Denko K.K.

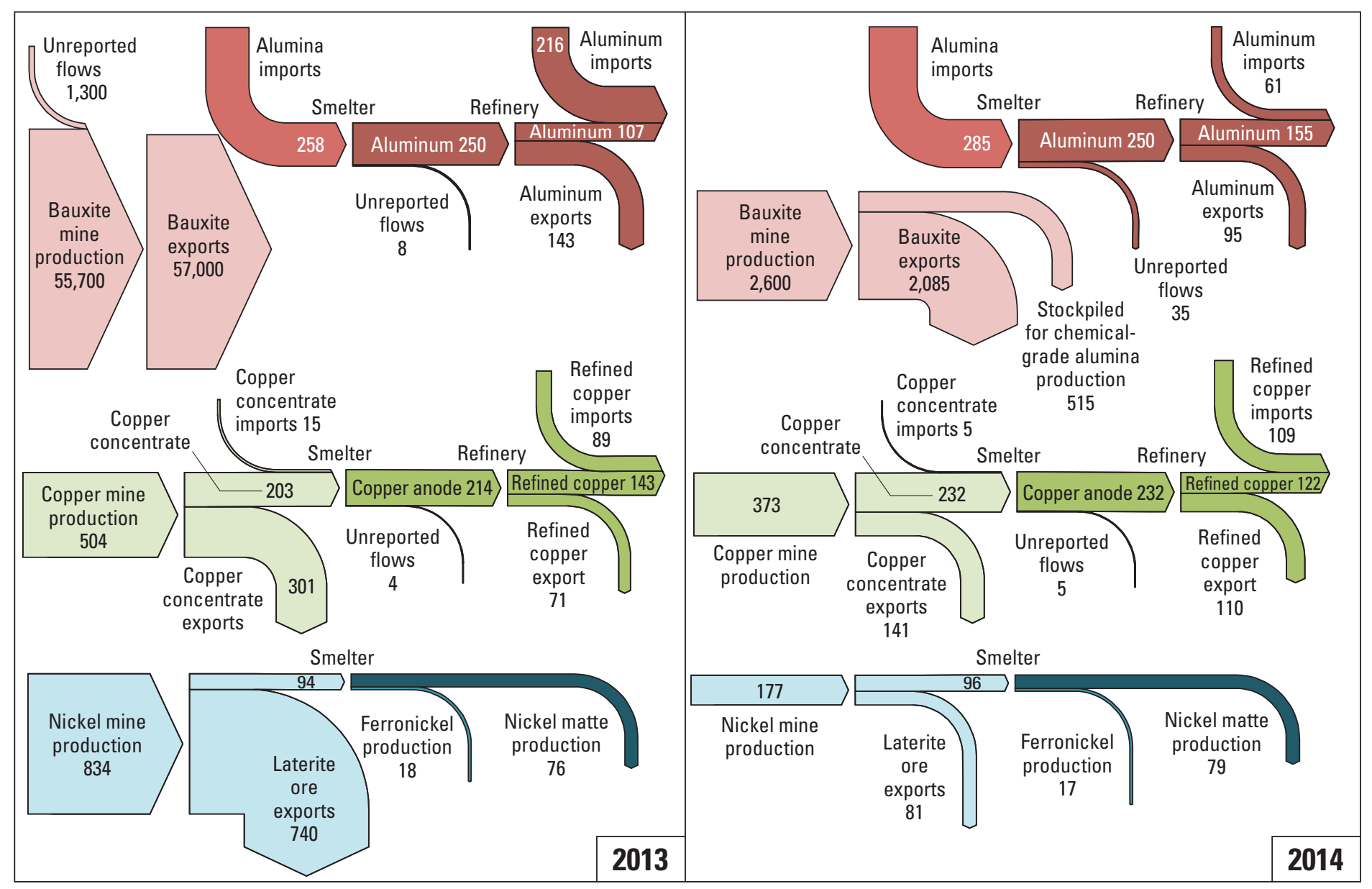

Figure 2. Flow diagrams of Indonesia's aluminum, copper, and nickel industries during 2013 and 2014. Quantities are in thousand metric tons of metal content, except for bauxite, which is in gross weight; alumina is produced from bauxite at a ratio of 1 to 2 and has an aluminum content of approximately 50 percent. Arrow widths are proportional to quantity of contained metal, except for bauxite in 2013 , which is scaled to 10 percent of its actual width. Sources: Bray, 2015a, 2016b; Brininstool, 2016; Kuck, 2016a, b; PT Aneka Tambang Tbk, 2016a, p. 103; PT Vale Indonesia Tbk, 2016, p. 112; United Nations Statistics Division, 2016; Wacaster, 2015. 
(20 percent). The share of foreign ownership complies with new regulations and Showa Denko K.K. has an offtake contract to sell 70 percent of the production capacity (Jensen, 2015). The Tayan refinery has the capability to consume roughly 850,000 wet metric tons per year $(\mathrm{t} / \mathrm{yr})$ of bauxite to produce $300,000 \mathrm{t} / \mathrm{yr}$ of chemical-grade alumina at full capacity; commercial operations commenced in 2015 with production of nearly 70,000 t (PT Aneka Tambang Tbk, 2016a, p. 28). At full production, the amount of bauxite consumed annually by the Tayan refinery represents less than 2 percent of 2013 production and is therefore not expected to significantly increase mine capacity utilization by the domestic bauxite industry.

In addition to the chemical-grade alumina refinery, PT Antam partnered with PT Inalum and Aluminum Corporation of China Ltd. (Chalco) to develop a smelter-grade alumina refinery in Mempawah, West Kalimantan, with a capacity of 2 million metric tons per year $(\mathrm{Mt} / \mathrm{yr})$ of alumina to supply PT Inalum's smelter (PT Aneka Tambang Tbk, 2016a, p. 211; 2016b). With the construction of an additional aluminum smelter in Kuala Tanjung, North Sumatra, PT Inalum aims to double aluminum production from a current capacity of $250,000 \mathrm{t} / \mathrm{yr}$ to a planned $500,000 \mathrm{t} / \mathrm{yr}$ by 2020 (Amirio, 2015). PT Well Harvest Winning Alumina Refinery, a joint venture owned by Harita Group, China Hongqiao Group Ltd., and other partners, plans to produce $4 \mathrm{Mt} / \mathrm{yr}$ of smeltergrade alumina by 2021 (Rusmana, 2015). Trial production at the refinery began in March 2016 and output is expected to reach $2 \mathrm{Mt} / \mathrm{yr}$ of alumina by the end of 2017 (Yam, 2016). In January 2016, China-based Shandong Nanshan Aluminium Co., Ltd. began constructing a $\$ 2$ billion manufacturing complex on Bintan Island, Riau Islands, with $2.1 \mathrm{Mt} / \mathrm{yr}$ of alumina refining capacity and 570,000 t/yr of aluminum smelting capacity (Jakarta Globe, 2015). The three forthcoming projects would significantly increase domestic refining capacity to $8 \mathrm{Mt} / \mathrm{yr}$ of alumina and smelting capacity to over $1 \mathrm{Mt} / \mathrm{yr}$ of aluminum in the next 5 years. With the addition of several other planned projects, Indonesia's domestic alumina and aluminum industries may consume 15 to $20 \mathrm{Mt} / \mathrm{yr}$ of bauxite by 2020 .

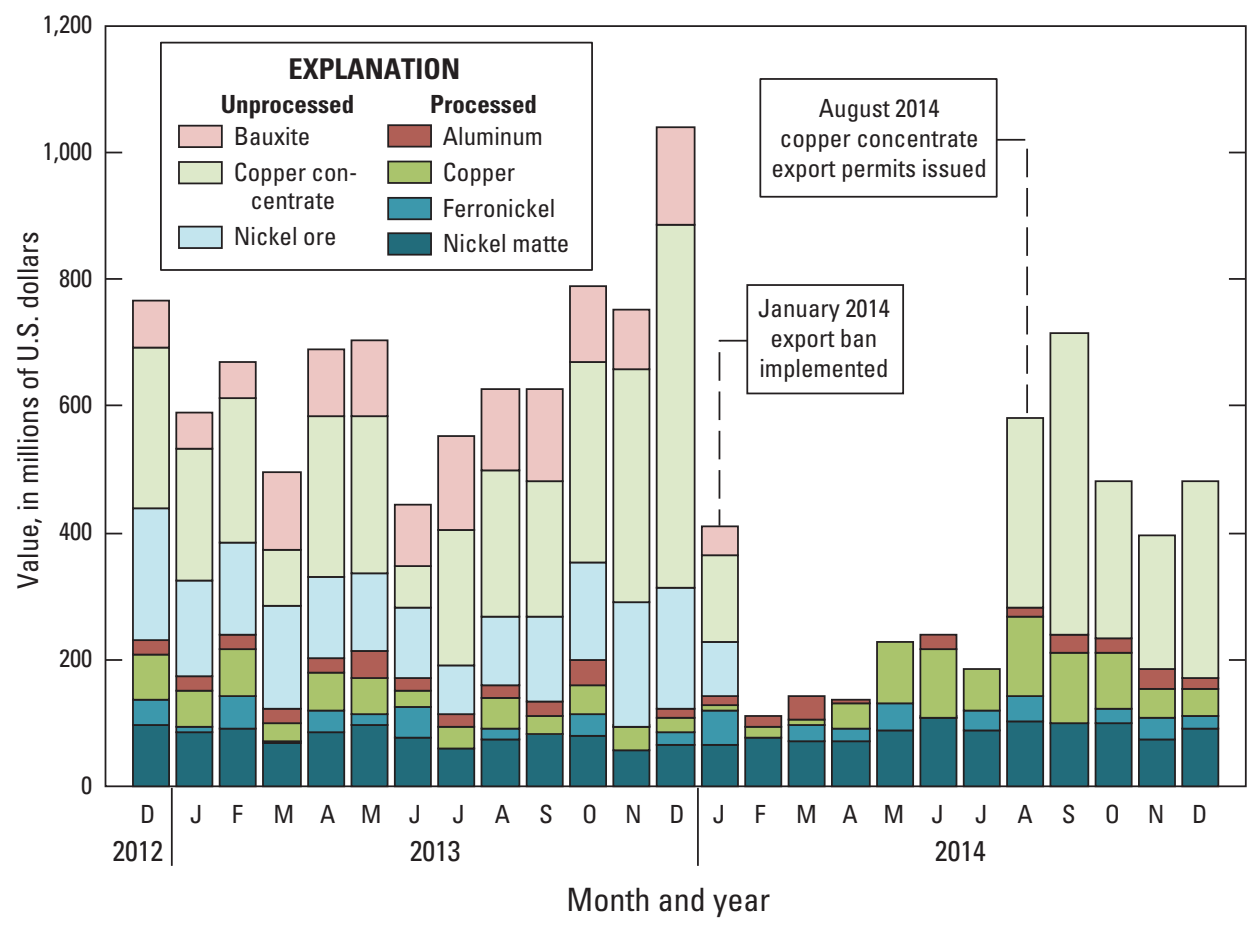

Figure 3. Indonesia's monthly exports of unprocessed mineral ores and processed metals from December 2012 through December 2014, based on Indonesia's reported trade (Badan Pusat Statistik, 2016).

\section{Copper}

Copper mine production decreased from 504,000 $\mathrm{t}$ of copper contained in concentrate in 2013 to $374,000 \mathrm{t}$ in 2014, reducing Indonesia's share of world copper production from 3 percent to 2 percent (fig. 1; Brininstool, 2016). Copper is mined at the Batu Hijau Mine on the island of Sumbawa, West Nusa Tenggara, by PT Newmont Nusa Tenggara (PT Newmont) and in the Grasberg minerals district in Papua Province, by PT Freeport Indonesia (PT Freeport). Prior to shipping, copper ore is processed into concentrate with an average copper content of 25 percent to 30 percent. In general, approximately one-half of Indonesia's annual copper concentrate production is processed domestically and the remainder is exported (fig. 2). By value, Japan consumed 35 percent of the copper concentrate exported from 2005 through 2014, whereas India, South Korea, and Spain each consumed about 16 percent; the share of exports destined for China increased from 4 percent in 2005 to 23 percent in 2014 (United Nations Statistics Division, 2016).

Temporary shutdowns and legal disputes between the Government of Indonesia and the foreign-owned mining companies contributed to a decline in production in 2014 (Taylor, 2014). U.S.-based Newmont Mining Corporation and Japan-based Sumitomo Corporation together own 56 percent of PT Newmont, having previously divested 44 percent ownership to Indonesian firms and offered the remaining 7 percent to the Government of Indonesia to comply with legal requirements. On June 30, 2016, Newmont and Sumitomo announced they would sell any remaining economic interest in Batu Hijau to Indonesian company PT Amman Mineral Internasional (Newmont Mining Corporation, 2016; Schonhardt and Hufford, 2016). U.S.-based Freeport-McMoRan Inc. currently owns a 90.64-percent stake in PT Freeport and agreed to divest an additional 20.64-percent interest to the Indonesian entities as part of a memorandum of understanding with the Government of Indonesia, which currently owns 9.36 percent (FreeportMcMoRan Inc., 2014). In terms of value, copper dominated Indonesia's mineral exports, with copper concentrate accounting for 93 percent of unprocessed mineral export value in 2014, even though Indonesia did not export copper concentrate from February through July of 2014 (fig. 3; Badan Pusat Statistik). Most of the value is added through 
mining and concentrating copper ore rather than through smelting and refining (U.S. Agency for International Development, 2013, p. 13). Indonesia's only copper smelter and refinery, located in Gresik, East Java, is operated by PT Smelting, which is owned by a consortium of Japanese companies (75 percent) and PT Freeport Indonesia (25 percent) (table 1; PT Smelting, undated). The Gresik refinery has a capacity of 300,000 t/yr and produced 214,000 t of refined copper in 2013 (Brininstool, 2016; PT Smelting, undated). After pursuing international arbitration and negotiations with the Government of Indonesia, copper producers PT Freeport and PT Newmont agreed to build additional smelting capacity in exchange for permission to export copper concentrate on a temporary basis until 2017. After the implementation of the ban in January 2014, export permits were not issued until August 2014, resulting in a 6-month hiatus in exports. Exports of copper concentrates amounted to $715,000 \mathrm{t}$ worth $\$ 1.7$ billion in 2014 , compared with the $1,454,000 \mathrm{t}$ worth $\$ 3$ billion exported in 2013 (United Nations Statistics Division, 2016). In order to renew its export permit in 2015, PT Newmont also agreed to transfer \$3 million to PT Freeport for domestic smelter development (Jensen and Asmarini, 2015a). Considering Indonesia's relatively small share of the global copper market, export restrictions are not expected to disrupt global copper prices or supplies.

\section{Nickel}

Nickel laterites containing 1 to 2 percent nickel were processed domestically in Indonesia and exported as direct shipping ore. Nickel mine production fell from a record high of $834,200 \mathrm{t}$ of contained nickel in 2013 to 177,000 t in 2014 (figs. 1, 2; Kuck, 2016a, b). Indonesia accounted for 31 percent of world nickel mine production in 2013 , but only 7 percent in 2014. In 2014, 4.2 Mt of nickel ore was exported before the ban went into effect in January, compared with the 64.8 Mt exported in 2013
(United Nations Statistics Division, 2016). By value, China consumed 71 percent of the nickel ore exported by Indonesia over the past decade, increasing from 0.2 percent of the total in 2005 to 96 percent in 2014. Over the same 10 years, Japan accounted for an average of 16 percent of nickel ore exports, and all others countries accounted for an average of 13 percent.

Direct shipping ore and processed forms of nickel accounted for 36 percent of Indonesia's total mineral export value in 2013 and 34 percent in 2014, despite the ban on ore exports (United Nations Statistics Division, 2016). Because nickel smelting adds substantial value, export revenue from nickel is dominated by processed forms. For example, less than 15 percent of the quantity of contained nickel production in 2013 was processed domestically into ferronickel and nickel matte, yet these products contributed 41 percent of the value of nickel exports (fig. 3; Kuck, 2016b; United Nations Statistics Division, 2016).

Demand for nickel ores since 2006 was driven mainly by increased nickel

Table 1. Major processing facilities and expansion projects completed or under construction in Indonesia since the 2014 mineral export ban.

[Capacities are in metric tons per year. Abbreviations: PT Antam, PT Aneka Tambang Tbk; PT Inalum, PT Indonesia Asahan Aluminium; Chalco, Aluminum Corporation of China Ltd.]

\begin{tabular}{|c|c|c|c|c|c|}
\hline Commodity & Operating company & Location & Province & Capacity & Reference \\
\hline Alumina & PT Indonesia Chemical Alumina & Tayan & West Kalimantan & 300,000 & PT Aneka Tambang Tbk (2016a) \\
\hline Alumina & PT Antam, PT Inalum, Chalco & Mempawah & West Kalimantan & $2,000,000$ & PT Aneka Tambang Tbk (2016b) \\
\hline Alumina & PT Well Harvest Winning Alumina Refinery & Ketapang & West Kalimantan & $4,000,000$ & Rusmana (2015) \\
\hline Alumina & Shandong Nanshan Aluminium Co., Ltd. & Bintan & Riau Islands & $2,100,000$ & Jakarta Globe (2015) \\
\hline Aluminum & Shandong Nanshan Aluminium Co., Ltd. & Bintan & Riau Islands & 570,000 & Jakarta Globe (2015) \\
\hline Aluminum & PT Inalum & Kuala Tanjung & North Sumatra & 500,000 & Amirio (2015) \\
\hline Copper, refined & PT Smelting & Gresik & East Java & 300,000 & PT Smelting (undated) \\
\hline Nickel in matte & PT Vale Indonesia & Sorowako & South Sulawesi & 120,000 & PT Vale Indonesia Tbk (2016) \\
\hline Nickel sulfide & PT Vale Indonesia & Pomalaa & Southeast Sulawesi & 15,000 & PT Vale Indonesia Tbk (2016) \\
\hline Nickel oxide & PT Vale Indonesia & Bahodopi & Central Sulawesi & 18,000 & PT Vale Indonesia Tbk (2016) \\
\hline Nickel & PT Weda Bay Nickel & East Halmahera & North Maluku & 65,000 & PT Aneka Tambang Tbk (2016a) \\
\hline Nickel in ferronickel & PT Karyatama Konawe Utara & Langgikima & Southeast Sulawesi & 40,000 & Jensen and Asmarini (2015b) \\
\hline Nickel in ferronickel & PT Antam & Pomalaa & Southeast Sulawesi & 30,000 & PT Aneka Tambang Tbk (2016a) \\
\hline Nickel in ferronickel & PT Antam & East Halmahera & North Maluku & 15,000 & PT Aneka Tambang Tbk (2016a) \\
\hline Nickel pig iron & PT Indoferro & Cilegon & Banten & 250,000 & PT Indoferro (2014) \\
\hline Nickel pig iron & PT Cahaya Modern Metal Industri & North Konawe & Southeast Sulawesi & 8,640 & Asmarini (2015) \\
\hline Nickel pig iron & PT Sulawesi Mining Investment & Morowali & Central Sulawesi & $1,200,000$ & Jensen and Burton (2015) \\
\hline
\end{tabular}


pig iron (NPI) production in China. NPI contains less than 15 percent nickel and provides a cheaper alternative to pure nickel for the production of stainless steel. In anticipation of the ban on nickel ore exports, Chinese NPI producers stockpiled Indonesian ores. Since the implementation of the ban, Chinese demand for nickel was met largely by drawing on stockpile inventories and from increased production of lower grade ore in the Philippines. Although analysts expected global nickel supply shortfalls as Philippine ore grades decline and Chinese NPI production slows, a global surplus remains (Home, 2016).

Approximately 100,000 t of contained nickel was processed domestically in 2013, equivalent to about 12 percent of Indonesia's total nickel mine production (Kuck, 2016b). In 2013 and 2014, PT Vale Indonesia Tbk produced approximately 80,000 t/yr of nickel in nickel matte (78 percent nickel content) at its Sorowako smelter in South Sulawesi, and exported it to Japan. As part of its agreement with the Government of Indonesia, PT Vale Indonesia will increase nickel production capacity at Sorowako to $120,000 \mathrm{t} / \mathrm{yr}$ of nickel, develop a $15,000-t / y r$ processing facility in Pomalaa, Southeast Sulawesi, and contribute to the development of a 18,000-t/yr processing facility in Bahodopi, Central Sulawesi (table 1; PT Vale Indonesia Tbk, 2016, p. 157, 163, 165). PT Antam produces approximately 20,000 t/yr of nickel in ferronickel (20 to 25 percent nickel content) at its Pomalaa smelter and exports its products to China, Europe, India, South Korea, and Taiwan (PT Aneka Tambang Tbk, 2016a, p. 15-17). In 2015, PT Antam planned to increase capacity at its Pomalaa smelter to $30,000 \mathrm{t} / \mathrm{yr}$ and construct a new ferronickel smelter in East Halmahera, North Maluku, with a capacity of 15,000 t/yr of nickel by 2018 (PT Aneka Tambang Tbk, 2016, p. 140). PT Weda Bay Nickel, which is 90 percent owned by Singapore-based Strand Minerals Pte., Ltd. and 10 percent owned by PT Antam, plans to produce 65,000 t/yr of nickel by sulfuric acid leaching of ore in East Halmahera, North Maluku (PT Aneka Tambang Tbk, 2016a, p. 225).

In addition to the planned nickel processing facilities and expansion projects, several NPI facilities are under development or have expansion plans. PT Indoferro began producing NPI with 2 to 5 percent nickel content in 2012 at its 250,000-t/yr facility in Cilegon, Banten, on the island of Java and aimed to increase production from $8,000 \mathrm{t}$ of contained nickel in 2014 to 12,000 $\mathrm{t}$ in 2015 (Jensen and Burton, 2014; PT Indoferro, undated). PT Cahaya Modern Metal Industri began producing NPI in 2013, began exports to China in 2014 , and received a 6-month permit to export 8,640 t of NPI in 2015 (Jensen and Burton, 2014; Asmarini, 2015). Backed by PT Bintang Delapan Mineral, China-based Tsingshan Holding Group, and Japan-based Hanwa Co., Ltd., PT Sulawesi Mining Investment began production at its Morowali facility in January 2015, operating at 60 to 70 percent of its capacity of $300,000 \mathrm{t} / \mathrm{yr}$ of NPI (Jensen and Burton, 2014, 2015). PT Sulawesi Mining Investment expects to complete construction of three smelters in June 2017 and plans to increase production capacity to 1.2 Mt/yr of NPI containing 120,000 t of nickel. PT Karyatama Konawe Utara, a subsidiary of China-based Hanking Industrial Group Co., Ltd., plans to expand ferronickel production to $40,000 \mathrm{t} / \mathrm{yr}$ (Jensen and Asmarini, 2015b). Several additional nickelprocessing facilities are expected to become operational in 2016, adding $767,000 \mathrm{t} / \mathrm{yr}$ of ferronickel production (Rusmana and Listiyorini, 2014; Jensen and Asmarini, 2015b).

Over the next few years, increased ferronickel, nickel matte, and nickel pig iron production may amount to $400,000 \mathrm{t} / \mathrm{yr}$ of nickel, less than one-half of peak mine production in 2013. These advanced-stage projects represent a subset of the nearly 40 nickel smelters proposed after the ban; however, construction will depend on favorable market conditions.

\section{Impact and Outlook}

Owing in part to the mineral export ban, Indonesia's gross domestic product (GDP) contracted by 2.4 percent from 2013 to 2014 (World Bank, 2015). The combined export value of unprocessed (that is, ores and concentrates) and processed (that is, refined metal) aluminum, copper, and nickel totaled $\$ 8$ billion or nearly 1 percent of Indonesia's GDP in 2013 and decreased to $\$ 4.1$ billion or approximately 0.5 percent of GDP in 2014 (World Bank, 2015; United Nations Statistics Division, 2016). The total value of processed aluminum, copper, and nickel exports increased slightly from $\$ 1.9$ billion in 2013 to $\$ 2.3$ billion in 2014 . Unprocessed mineral exports of bauxite, copper concentrate, and nickel ore totaled $\$ 6$ billion in 2013 and decreased by 70 percent to $\$ 1.8$ billion in 2014 . Thus, nearly two-thirds of the $\$ 6.5$ billion decrease in total exports from Indonesia was directly attributable to the ban on unprocessed mineral exports in 2014.

Ultimately, the result of Indonesia's mineral export ban will depend on the balance of short-term losses in revenue and employment against longer term development of downstream processing capacity. The export ban stimulated an increase in foreign direct investment in 2014 as over 50 smelter projects were planned (Sambijantoro, 2014). With slowing economic growth in China and lower commodity prices, the valueadded benefit derived from additional processing capacity may not offset the investment required and loss of export revenue (Winzenried and Adhitya, 2014).

Policies enacted by Indonesia reflect a broader trend among developing counties seeking greater control over the extraction of natural resources (Kean, 2014). The full effect of Indonesia's mineral export ban on the global economy may have been offset by alternative sources of raw material supplied by other countries. Following the ban in Indonesia, bauxite production in Malaysia and nickel ore production in the Philippines increased dramatically owing to demand from China (Jensen and Burton, 2014; Rusmana, 2015). However, environmental degradation prompted a temporary moratorium on bauxite mining in Malaysia and may prompt new regulations on open-pit mining in the Philippines (Serapio and Dela Cruz, 2016; Sipalan and Chow, 2016). With natural resource policies having been proposed in the Philippines, South Africa, and Zambia (Kean, 2014), the impacts of resource nationalism in Indonesia may be closely watched by other producers and remain a subject of great interest. 


\section{References Cited}

Amirio, Dylan, 2015, Inalum expands capacity to double production: The Jakarta [Indonesia] Post, October 16, accessed February 25, 2016, at http://www.thejakartapost.com/ news/2015/10/16/inalum-expands-capacity-double-production.html.

Anderson, C.S., 2015, Tin: U.S. Geological Survey Mineral Commodity Summaries 2015, p. 168-169. [Also available at http://minerals.usgs.gov/minerals/pubs/commodity/tin/ mcs-2015-tin.pdf.]

Anderson, C.S., 2016, Tin: U.S. Geological Survey Mineral Commodity Summaries 2016, p. 174-175. [Also available at http://minerals.usgs.gov/minerals/pubs/commodity/tin/ mcs-2016-tin.pdf.]

Asmarini, Wilda, 2015, Indonesia issues list of six-month mining export permits: Thomson Reuters, March 19, 2015, accessed March 21, 2016, at http://www.reuters.com/article/ indonesia-minerals-exports-idUSL3N0WL2D920150319.

Asmarini, Wilda, 2016, Indonesia evaluating mining rules as 2017 deadline on metal exports nears: Thomson Reuters, September 8, 2016, accessed September 12, 2016, at http://www.reuters.com/article/indonesia-mining-idUSL3N1BJ2TK.

Badan Pusat Statistik, 2016, Exports and imports [December 2012 through December 2014 Harmonized System commodity codes 2603, 2604, 2606, 281820, 720260, 740311, 750110, 760110 for aluminum, copper, and nickel]: Badan Pusat Statistik, accessed August 4, 2016, at https://www.bps.go.id/all_newtemplate.php.

Bray, E.L., 2015a, Aluminum [advance release], in Metals and minerals: U.S. Geological Survey Minerals Yearbook 2014, v. I, p. 5.1-5.20, accessed June 29, 2016, at $\mathrm{http} / / /$ minerals.usgs.gov/minerals/pubs/commodity/aluminum/myb1-2014-alumi.pdf.

Bray, E.L., 2015b, Bauxite and alumina [advance release], in Metals and minerals: U.S. Geological Survey Minerals Yearbook 2013, v. I, p. 10.1-10.13, accessed June 29, 2016, at http://minerals.usgs.gov/minerals/pubs/commodity/bauxite/ myb1-2013-bauxi.pdf.

Bray, E.L., 2016a, Bauxite and alumina: U.S. Geological Survey Mineral Commodity Summaries 2016, p. 32-33. [Also available at http://minerals.usgs.gov/minerals/ pubs/commodity/bauxite/mcs-2016-bauxi.pdf.]

Bray, E.L., 2016b, Bauxite and alumina [advance release], in Metals and minerals: U.S. Geological Survey Minerals Yearbook 2014, v. I, p. 10.1-10.13, accessed June 29, 2016 , at http://minerals.usgs.gov/minerals/pubs/commodity/bauxite/myb1-2014-bauxi.pdf.

Brininstool, Mark, 2015, Copper [advance release], in Metals and minerals: U.S. Geological Survey Minerals Yearbook 2013, v. I, p. 20.1-20.29, accessed June 29, 2016, at http://minerals.usgs.gov/minerals/pubs/commodity/copper/myb1-2013-coppe.pdf.

Brininstool, Mark, 2016, Copper [advance release], in Metals and minerals: U.S. Geological Survey Minerals Yearbook 2014, v. I, p. 20.1-20.28, accessed August 2, 2016, at http://minerals.usgs.gov/minerals/pubs/commodity/copper/myb1-2014-coppe.pdf.

Freeport-McMoRan Inc., 2014, Freeport-McMoRan announces resumption of exports from Indonesian subsidiary: Phoenix, Arizona, Freeport-McMoRan Inc. news release, July 25, 2014, accessed February 25, 2016, at http://www.fcx.com/news/2014/072514.pdf.

Home, Andy, 2016, COLUMN-How to explain China's surprising metals trade figures?: Thomson Reuters, January 26, 2016, accessed April 18, 2016, at http://www.reuters.com/ article/china-trade-ahome-idUSL8N15C3H3.

Jakarta Globe, 2015, Chinese firm to kick off construction on Bintan bauxite smelter in January: Jakarta [Indonesia] Globe, December 4, 2015, accessed January 11, 2016, at http://jakartaglobe.beritasatu.com/business/chinese-firm-kick-off-construction-bintanbauxite-smelter-january/.

Jensen, Fergus, 2015, Indonesian alumina refinery starts up, Japan to take most output: Thomson Reuters, February 11, 2015, accessed March 16, 2016, at http://www.reuters.com/ article/indonesia-aluminium-antam-idUSL4N0VL1MM20150211.

Jensen, Fergus, and Asmarini, Wilda, 2015a, Newmont gets 6-mth quota to export 430,000 T of copper concentrate from Indonesia: Thomson Reuters, November 20, 2015, accessed February 25, 2016, at http://www.reuters.com/article/indonesia-newmontmining-exports-idUSJ9N12X00I20151120.

Jensen, Fergus, and Asmarini, Wilda, 2015b, UPDATE 1-Nickel smelter developers shelve Indonesia projects amid credit squeeze: Thomson Reuters, November 18, 2015, accessed March 21, 2016, at http://www.reuters.com/article/indonesia-nickelidUSL3N13D3SG20151118.

Jensen, Fergus, and Burton, Melanie, 2014, Tsingshan eyes first Indonesian nickel pig iron output in Jan: Thomson Reuters, September 4, 2014, accessed March 21, 2016, at http://www.reuters.com/article/indonesia-nickel-tsingshan-idUSL3N0R42WI20140904.

Jensen, Fergus, and Burton, Melanie, 2015, LME WEEK-Nickel pig iron producer in Indonesia to triple capacity by May: Thomson Reuters, October 14, 2015, accessed March 21, 2016, at http://www.reuters.com/article/metals-lmeweek-indonesia-nickelidUSL8N12D0TC20151014.

Kean, Angela, 2014, Indonesia's mineral export ban may kick off global trend: S\&P Global Market Intelligence, November 24, 2014, accessed February 25, 2016, at https://www.snl.com/InteractiveX/article.aspx?ID=29981809\&KPLT=2.

Kuck, P.H., 2016a, Nickel: U.S. Geological Survey Mineral Commodity Summaries 2016 p. 114-115. [Also available at http://minerals.usgs.gov/minerals/pubs/commodity/ nickel/mcs-2016-nicke.pdf.]

Kuck, P.H., 2016b, Nickel [advance release], in Metals and minerals: U.S. Geological Survey Minerals Yearbook 2013, v. I, p. 51.1-51.31, accessed June 29, 2016, at http://minerals.usgs.gov/minerals/pubs/commodity/nickel/myb1-2013-nicke.pdf.
Newmont Mining Corporation, 2016, Newmont enters agreement to sell interest in Indonesian assets: Denver, CO, Newmont Mining Corporation press release, June 30, 2016, accessed June 30, 2016, at http://www.newmont.com/newsroom/newsroom-details/ 2016/Newmont-Enters-Agreement-to-Sell-Interest-in-Indonesian-Assets/default.aspx.

PT Aneka Tambang Tbk, 2016a, 2015 annual report: PT Aneka Tambang Tbk, 685 p., accessed March 21, 2016, at http://www.antam.com/images/stories/joget/file/annual/ 2015/ar_antam_2015.pdf.

PT Aneka Tambang Tbk, 2016b, ANTAM \& INALUM sign joint venture agreement (JVA) on the development of smelter grade alumina refinery (SGAR) plant: PT Aneka Tambang Tbk, April 14, 2016, accessed August 2, 2016, at http://www.antam.com/index. php?option=com content\&task=view\&Itemid $=144 \& \mathrm{id}=915$.

PT Indoferro, [undated], About us: PT Indoferro, accessed August 2, 2016, at http://www.indoferro.growthsteelgroup.com/the_group.php.

PT Smelting, [undated], About us: PT Smelting, accessed June 29, 2016, at http://www.ptsmelting.com/aboutus.htm.

PT Vale Indonesia Tbk, 2016, 2015 annual report: PT Vale Indonesia Tbk, 446 p., accessed March 21, 2016, at http://www.vale.com/indonesia/EN/investors/indonesia-investors/ information-market/annual-reports/annualreport/PT\%20Vale $\% 20$ Indonesia $\% 20$ Tbk $\% 20$ Annual\%20Report\%20\%202015.pdf.

Rusmana, Yoga, 2015, 'Malaysia is the winner'; Indonesia miners go overseas after ban: Bloomberg, June 26, 2015, accessed February 25, 2016, at http://www.bloomberg.com/ news/articles/2015-06-26/-malaysia-is-the-winner-indonesia-miners-go-overseas-after-ban.

Rusmana, Yoga, and Listiyorini, Eko, 2014, Nine nickel smelters seen in Indonesia this yr after ban: Bloomberg, May 12, 2014, accessed February 25, 2016, at http://www.bloomberg.com/news/articles/2014-05-12/nine-nickel-smelters-plannedin-indonesia-this-year-after-ban.

Sambijantoro, Satria, 2014, Mining law boosts foreign investment: The Jakarta [Indonesia] Post, July 25, 2015, accessed February 25, 2016, at http://www.thejakartapost.com/ news/2014/07/25/mining-law-boosts-foreign-investment.html.

Schonhardt, Sara, and Hufford, Austen, 2016, Newmont Mining to sell Indonesian mine for $\$ 1.3$ billion: The Wall Street Journal, June 30, 2016, accessed June 30, 2016, at http://www.wsj.com/articles/newmont-mining-to-sell-indonesian-mine-for-920million-1467285254.

Serapio, Manolo, Jr., and Dela Cruz, Enrico, 2016, Philippines to review all mines as environmentalist takes the helm: Thomson Reuters, July 1, 2016, accessed July 5, 2016, at http://www.reuters.com/article/us-philippines-mining-idUSKCN0ZG39O.

Sipalan, Joseph, and Chow, Emily, 2016, UPDATE 1-Malaysia extends bauxite mining ban by another three months: Thomson Reuters, April 8, 2016, accessed June 29, 2016, at http://www.reuters.com/article/malaysia-bauxite-idUSL3N17B1TW.

Taylor, Michael, 2014, UPDATE 1-Newmont seeks international arbitration over Indonesia mining export curbs: Thomson Reuters, July 1, 2014, accessed September 13, 2016, at http://www.reuters.com/article/newmont-mining-indonesia-arbitration-idUSL4N0PC2M820140701.

Tse, P.-K., 2006, The mineral industries of Indonesia and East Timor (Timor-Leste), in Area reports-International-Asia and the Pacific: U.S. Geological Survey Minerals Yearbook 2003, v. III, p. 12.1-12.11. [Also available at http://minerals.usgs.gov/ minerals/pubs/country/2003/myb3-2003-id-tt.pdf.]

United Nations Statistics Division, 2016, United Nations Commodity Trade Statistics Database (UN Comtrade) [Indonesia's imports and exports, December 2012 through December 2014, Harmonized System commodity codes 2603, 2604, 2606, 281820, 720260, $740311,750110,760110$ for aluminum, copper, and nickel]: United Nations Commodity Trade Statistics Database, accessed March 21, 2016, at http://comtrade.un.org/data/.

U.S. Agency for International Development, 2013, Economic effects of Indonesia's mineral-processing requirements for export: U.S. Agency for International Development, April 2013, 60 p. plus 2 appendixes, accessed February 25, 2016, at http://pdf.usaid.gov/pdf docs/pbaaa139.pdf.

Wacaster, Susan, 2015, The mineral industry of Indonesia [advance release], in Area reports-International-Asia and the Pacific: U.S. Geological Survey Minerals Yearbook 2013, v. III, p. 12.1-12.7, accessed June 29, 2016, at http://minerals.usgs.gov/ minerals/pubs/country/2013/myb3-2013-id.pdf.

Winzenried, Sacha, and Adhitya, Fandy, 2014, Challenging times ahead for Indonesian mining sector: Price Waterhouse Cooper, February 2014, accessed February 25, 2016, at https://www.pwc.com/id/en/media-centre/pwc-in-news/2014/english/challenging times_ahead_for_the_indonesian_mining_sector.html.

World Bank, 2015, Indonesia [data by country]: World Bank data, accessed March 21, 2016, at http://data.worldbank.org/country/indonesia.

Yam, Polly, 2016, China Hongqiao starts alumina output in Indonesia, up bauxite from Guinea: Thomson Reuters, March 14, 2016, accessed March 21, 2016, at http://af.reuters.com/article/metalsNews/idAFL3N16M27G

For more information, contact:

Director, National Minerals

Information Center

U.S. Geological Survey

12201 Sunrise Valley Drive

988 National Center

Reston, VA 20192
Email: nmicrecordsmgt@usgs.gov

Or visit the USGS Minerals Information

Web site at

http://minerals.usgs.gov/minerals/ 